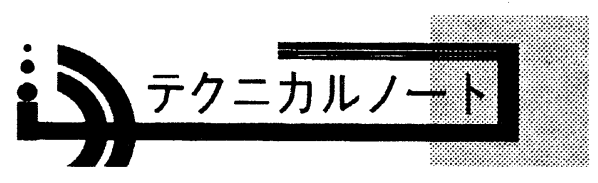

\title{
$200 \mathrm{~mm}$ 管における気液二相流実験 \\ Two-Phase Flow Study Using 200mm Diameter Pipe
}

\author{
亀 田 泰 武 \\ KAMEDA Yasutake
}

\author{
森田泰治郎 \\ MORITA Taijirou
}

\begin{abstract}
A two-phase flow experiment was conducted using a $200 \mathrm{~mm}$ diameter, $100 \mathrm{~m}$ long straight pipe with adjustable gradient. A steel pipe with transparent plastic parts was used. Superficial water and air velocities were from 0 to $1.5 \mathrm{~m} / \mathrm{s}$ and 0 to $10 \mathrm{~m} / \mathrm{s}$. Pipe gradients were horizontal, $0.2 \%$ up, $0.8 \%$ up and $0.5 \%$ down. Test results were as follows, 1. Observed flow pattern in horizontal and inclined pipe was almost the same as that of the preceding $300 \mathrm{~mm}$ pipe experiment. Flow pattern is extremely sensitive to pipe gradient. 2. Intermittent flow pressure loss was relatively low by comparison with that reported in the literature on the matter. Its pressure loss was between the mixed flow model pressure loss and the separated flow model pressure loss. An empirical formula of pressure loss was obtained. 3 . Void fraction of intermittent flow was also relatively low compared with other reports. It was concluded that low up-gradient did not affect the void fraction but down-gradient did. An empirical formula of void fraction was obtained. 4. Up-gradient flow showed an air lift effect which was consistent with the void fraction.
\end{abstract}

Keywords: Two-Phase Flow Experiment, 200mm Diameter, Ajustable Gradient, Void, Pressure Loss, Flow-Pattern

\section{1.はじめに}

大ロ径管の二相流流動状況、圧力損失、ボ イド率などは小ロ径管と異なると言われてい るがこれまで実験の報告は少なかった。今回、 $300 \mathrm{~mm}$ 管の実験 [1]に引続き $200 \mathrm{~mm}$ 管の実験 とその状況の回帰分析を行ったものである。 データのばらつきが大きいため、 $200 \mathrm{~mm}$ 管 では実験条件、平均データの取扱い方など改 善を図った。

\section{2. 実験装置の概要}

\section{1 実験施設および施設能力の概要}

循環式管路流実験装置[1]を基本とし、二 相流流れの基本となる水平管に加え、順勾配 管および逆勾配管の実験を実施した。

(1)下り勾配 $0.5 \%$ (2)上り勾配 $0.8 \%$ (3)上

\section{り勾配 $0.2 \%$ (4)水平管}

見かけ速度は、 $J_{\mathrm{L}}=1.5 \mathrm{~m} / \mathrm{s} 、 J_{\mathrm{A}}=10 \mathrm{~m} / \mathrm{s}$ を最大值とした。

\section{2 . 2 測定方法}

\section{2. 1 圧力測定}

実験本管 9 箇所に、ピエゾメータを取り付

* 1993.4.2 受付

** 建設省都市局流域下水道課

テ110 千代田区霞ヶ関2-1-3 TEL(03) 3580-4311

$†$ †陎モリ 
けて圧力をマノメータに導き、珐力水頭を測 定した。ピエゾメータは内径 $4 \mathrm{~mm}$ 、マ、マ メータは内径 $100 \mathrm{~mm}$ の透明円筒を用いた。 この内径の差により、サージタンク効果が生 じるため、圧力の変動による誤差を小さくす ることができた。

\section{2 . 2 ボイド率}

実験本管の内側に容量式波高計センサー部 を取り付け、本管内部の水位変動を測定し、 その水面の位置からボイド率を算出した。

また、実験本管透明部分での目視観察によ る水面測定值とセンサ一出力と照合し、必要 に応じて補正した。

\subsection{3 流況（フローパターン）観察}

液相(水)を着色し、ビデオ撮影を各ケース $1 \sim 5$ 分間行った。また、目視にてフローパ ターンを判定し、記録した。

\section{2 . 4 液相(水)流量}

J I S に基づく四角堰により、堰越流水深 を計測し、J I S 公式を用いて流量を求めた。 越流水深は、1/10mmバーニヤ目盛り付きの ポイントゲージで測定した。

\section{2.5 気相(空気)流量}

熱線式デシタル風速計を、気液分離槽に取 り付け、管路を通り過ぎてきた空気量を大気 圧 $(760 \mathrm{mmHg})$ で測定した。

\section{3. 流動様式}

\section{1 水平管}

Fig.3.1に実験によって得られた流動状況 を示す。図には Baker 及び Weisman が与え た流動様式境界線を示した。分離流と間欠流 が主体であるが、高流速域では噴霧流への遷 移域が見られる。

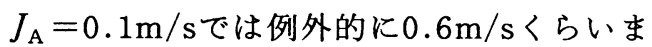
で分離流を示すが、 $J_{\mathrm{A}}$ が $0.2 \mathrm{~m} / \mathrm{s}$ 以上のケー スでは分離流と間欠流の境界線は、 $J_{\mathrm{L}}=0.26$ 〜0.3m/sに並んでいる。

前回の $300 \mathrm{~mm}$ 管[1]で得られた流動様式境 界を式(3-1)に示す。

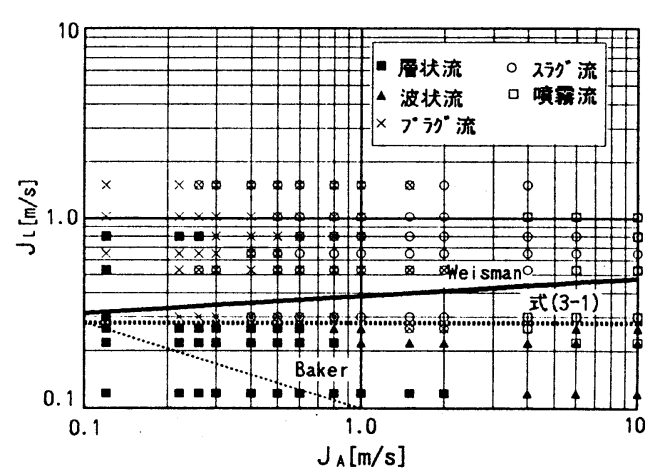

Fig. 3.1 Flow pattern in horizontal flow.

$$
J_{\mathrm{A}} /(g \cdot D)^{1 / 2}=0.25\left(J_{\mathrm{A}} / J_{\mathrm{L}}\right)
$$

この式を $200 \mathrm{~mm}$ 管にあてはめると $J_{\mathrm{L}}=0.28$ $\mathrm{m} / \mathrm{s}$ となが、この値は、今回の実験結果と ほぼ一致する。Weisman[2]は、分離流と間 欠流の境界式として、Taitel-Dukler 式を参 考に、次式を得た。

$$
J_{\mathrm{A}} /(g \cdot D)^{1 / 2}=0.25\left(J_{\mathrm{A}} / J_{\mathrm{L}}\right)^{1.1}
$$

Fig. 3.2 2横軸を $J_{\mathrm{A}} / J_{\mathrm{L}}$ 、縦軸を $J_{\mathrm{A}} /(\mathrm{gD})^{0.5}$ とした流動様式について実験結果と式(3-1)、 (3-2)の対応を示す。

式（3-1）は、実験結果及び式(3-2) と同様 な傾向を示している。

\section{2 上り勾配管}

$0.2 \% 、 0.8 \%$ 管とも分離流はなく、間欠流 が支配的であった。勾配の铛妙な変化で流動 様式が変化するのは、分離流の状況が水平勾 配付近で非常に不安定であることを示す。

\section{3 下り勾配管}

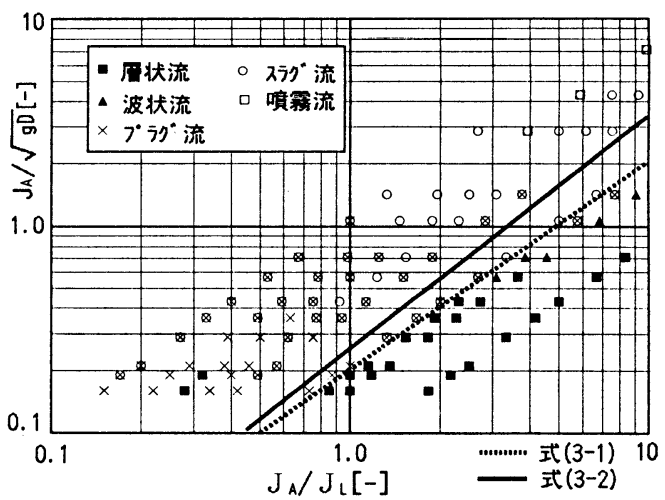

Fig. 3.2 Flow pattern in horizontal flow. 


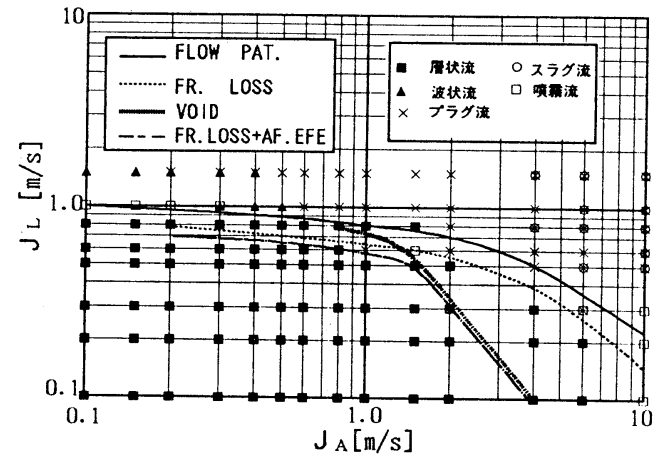

Fig.3.3 Flow pattern in pipe gradient $0.5 \%$ down flow.

Fig. 3.3に0.5\%下り勾配の流動状況を示し た。 $300 \mathrm{~mm}$ 管と同様に間欠流と分離流の境 界線が相当高流速に移動していることが示さ れる。 $J_{\mathrm{A}}$ が $10 \mathrm{~m} / \mathrm{s}$ 程度になると境界線が下が り水平管と同じ程度までになる。Fig. 3.3に はボイド率の状況、圧力損失状況から推定し た境界線を示す。これらは、 $J_{\mathrm{A}}$ が増加して、 それまで一定值であったものが变化を開始す る境界である。これらの境界線は流動様式境 界線と近いが、分離流よりに位置している。

\section{4. 圧力損失}

\section{1 満管流}

\section{1. 1 王力損失の基本式}

圧力損失算定式は Darcy-Weisbach 式を 基本として考えていくことができる。このう ち摩擦係数入について各種のものが用いられ ているが、大口径管においてはRe数が大き くなる関係から、一定とも考えられる。また、 河川、上下水道に打ける大口径水路では

Manning 式が多く用いられている。

a. Darcy-Weisbach式 (以後D-W式という) 圧力損失は

$$
\mathrm{d} P_{\mathrm{f}} / \mathrm{d} z=\lambda / 2 D \cdot V^{2} \cdot \rho
$$

これを、水頭損失勾配 I で表すと

$$
I=\lambda / 2 D \cdot V^{2} / \mathrm{g}
$$

圧力損失勾配 $I$ は、水柱高として表された
圧力変化を長さで割った值である。

このうち、摩擦係数について次式が提出さ れている。

a. 1 Blasius式

$$
\lambda=0.3164 / R e^{0.25}
$$

\section{a. 2 Moody簡略式[3]}

$$
\lambda=0.0055\left\{1+\left(20000 \varepsilon / D+10^{6} / R e\right)^{0.5}\right\}
$$

ここで $\varepsilon ：$ 等価粗さ $[\mathrm{m}]$ である。

\section{b. Manning 式}

下水道など開水路で一般に使用されている Manning 式は次式となる。

$$
\mathrm{d} P_{\mathrm{f}} / \mathrm{d} z=n^{2} \cdot V^{2} \cdot g \cdot \rho / R^{4 / 3}
$$

ここで、 $n$ は粗度係数で、滑らかな場合 0.01 〜0.013となり、 $R$ は径深（断面積／潤辺） である。上式をD-W式に換算すると同じ管 径では入が一定となる。

\subsection{2 データおよび各式の比較}

これらの式とデータの比較を行う場合、圧 力損失は流速の二乗にほ皃比例するため、流 速が小さい場合と大きな場合で差が非常に大 きくなり、広い範囲での比較が難しくなる。 このため、 D-W式の管摩擦係数入に換算し て比較を行った。

これを換算摩擦係数 $\lambda_{\mathrm{c}}$ とし、次式により 求める。

$$
\lambda_{\mathrm{c}}=\mathrm{d} P_{\mathrm{f}} / \mathrm{d} z \cdot 2 \cdot D /\left(J_{\mathrm{T}}^{2} \cdot \rho\right)
$$

この結果、気相容積流束、液相容積流束が 一桁以上違う場合でもグラフ化がしやすい。 ここで、二相流の場合、容積流束は $J_{\mathrm{A}}+J_{\mathrm{L}}$ で、密度は二相の平均密度 $\left(J_{\mathrm{A}} \cdot \rho_{\mathrm{A}}+J_{\mathrm{L}} \cdot \rho_{\mathrm{L}}\right) /$ $\left(J_{\mathrm{A}}+J_{\mathrm{L}}\right)$ で表すと上式は次式となる。

$$
\begin{aligned}
\lambda_{\mathrm{C}}= & \left(\mathrm{d} P_{\mathrm{f}} / \mathrm{d} z\right) \cdot 2 D /\left\{\left(J_{\mathrm{A}} \cdot \rho_{\mathrm{A}}+J_{\mathrm{L}} \cdot \rho_{\mathrm{L}}\right) \cdot\right. \\
& \left.\left(J_{\mathrm{A}}+J_{\mathrm{L}}\right)\right\}
\end{aligned}
$$

4. 1.3 液相単相流での実験值との比較 単相流のデータを、各式および係数の比較 
を行った。

二相流の実験データは液相単相のデータを 出発点とし、気相流量が増加していくにつれ 変化していくことから二相流のデータ解析に 重要である。

$\lambda_{\mathrm{c}}$ は0.024〜0.027 と高い值となり、これ は鋼管を使用し、相対的に管表面が粗いため である。各式の係数をデータにあわせて示し てある。図中、Moody 式において $\varepsilon$ は $0.3 \mathrm{~mm}$ とし、Manning式における粗度係数は 0.011 とした。Fig.4-1に実験データから算出した $\lambda_{\mathrm{c}}$ と各式から算出した $\lambda_{\mathrm{c}}$ を示している。

Blasius 式など、入をRe数だけで推算される 值はデータよりも小さい值を示す。このこと から管の滑らかさの状態を把握しないと二相 流の圧力損失、流速などの推計に大きな誤差 がでることを示している。実験データからそ れほど離れておらず、計算が比較的簡単なた め、Manning 式を主に考えて解析を行った。

4. 2 水平管二相流珐力損失算定モデル

\section{2. 1 王力損失の推算}

大口径長距離二相流では送水のためのエネ ルギー・コストが大さいため、経済的な検討 が重要である。送水エネルギーは流速の 2 乗 に比例するため、今回の実験範囲以上の流速 はエネルギーが大きくなり過ぎ実用的ではな い。このため、压力損失の推定の検討は間欠 流を中心に行らこととした。

$300 \mathrm{~mm}$ 管実験では回帰式として次の式を 得ている $[1]$ 。

$$
I_{\mathrm{TP}}=I_{\mathrm{LO}} \cdot\left(1+J_{\mathrm{A}}{ }^{2} / J_{\mathrm{L}}{ }^{2}\right) 0.3
$$

\section{$I_{\text {Lo }}$ : 水単相流の圧力損失勾配}

上式は $J_{\mathrm{A}}$ が増えていくと合わないことが 想定されるため、今回はより実態に近いと考 えられる回㷌式を考えた。LockhartMartinelli[4]は、注大気圧下の空気一夜 系断熱二相流の測定結果に基づいて、摩摖損 失とボイド率を予測する L-M相関法を提案 している。この方法では二相流の摩擦損失を、 夜相成分だけが、あるいは気相成分だけが単
相流として流れたときの摩擦損失勾配に対す る比として表している。ただし，その比の差 は大きい。

\subsection{2 圧力損失回帰モデル} 次の 2 種類のモデルを考えた。

\section{a . 気液が混合して流れる状態のモデル（M} モデル)

完全に混合した単相流で、水と空気の実流 速が同じと考える。その密度 $\rho_{\mathrm{TP}}$ は気液二相 の合成であるとした。Manning 式は、水の 自然流下の計算に用いられている式であるが、 今回は気相についても適用することにした。 ただし、密度についての項が必要であり、次 式とした。

$$
I=R_{\mathrm{A}}^{(-4 / 3)} \cdot \mathrm{n}^{2} \cdot J_{\mathrm{TP}}^{2} \cdot \rho_{\mathrm{TP}} / \rho_{\mathrm{L}}
$$

摩擦損失係数は Blasius 型の場合は粘性係 数 $\mu$ の関数となり、4 通りの表し方 $[5]$ 的あ るとされている。(1)クオテイ比で重み付け する（Cicchittiによる）、(2)容積流束の比で 重み付けする（Duklerによる）、(3)平均密 度に似た形で重み付けする（McAdamsによ る）、(4)水の粘性係数とする。

$J_{\mathrm{A}} / J_{\mathrm{L}}$ が10のとき、入は粘性係数の $1 / 4$ 乗 になるため(2)は(4)の 6 割程度である。

Moodyの流速式では、 $R e$ 数の計算で $\mu$ は (2)型と考える。

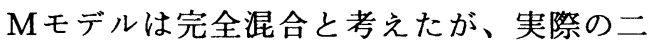
相流は空気が速く水が遅く流れるため、圧力 損失の主体である水の断面積が大きくなって、 流速が少なくなり、圧力損失はもっと小さい ものとなる。

b . 気液が二層に分離して流れる状態のモデ ル ( $S$ モデル)

気液二相が層状流のよ5に分離して、お互 いに影響を与えることなく流れる状態を考え る。この場合二相の圧力損失が同じで流れる ものとする。

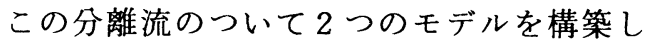
た。

\section{b. 1 置き換えモデル（ $，$ モデル）}

第一の考え方は、空気を水で置き換えるも 
のである。空気流を同じ流下面積で同じ圧力 損失となる水に換算し、全体を水としての単 相流で考えるものである。これにより、換算 液相流速を計算する。この考え方は、分離流 といっても、計算は単相流に近いものとなる。 また、気相実速度が夜相実速度より大さいこ とによる液相の加速や境界面の乱れによる圧 力損失が加味されないこととなる。

分離流の空気の摩擦損失は、

$\mathrm{d} P_{\mathrm{A}} / \mathrm{d} z=\lambda_{\mathrm{A}} / 2 D_{\mathrm{A}} \cdot V_{\mathrm{A}}{ }^{2} \cdot \rho_{\mathrm{A}}$ となり、こ れを水で置き換えると、

$\mathrm{d} P_{\mathrm{L}} / \mathrm{d} z=\lambda_{\mathrm{L}} / 2 D_{\mathrm{A}} \cdot V_{\mathrm{L}}{ }^{2} \cdot \rho_{\mathrm{L}}$ となる。

この際、流下断面積および圧力損失が同じ とする。

$\mathrm{d} P_{\mathrm{A}} / \mathrm{d} z=\mathrm{d} P_{\mathrm{L}} / \mathrm{d} z$ の条件から、 $\lambda_{\mathrm{A}} \cdot V_{\mathrm{A}}{ }^{2} \cdot \rho_{\mathrm{A}}=\lambda_{\mathrm{L}} \cdot V_{\mathrm{L}}{ }^{2} \cdot \rho_{\mathrm{L}}$ となり、 Manning 式では $\lambda_{\mathrm{A}}=\lambda_{\mathrm{L}}$ と考えられるので、 大気圧の場合は次の値となる。

$$
J_{\text {cL }}=0.0346 \cdot J_{\mathrm{A}}
$$

Moody式の場合、換算が複雑になるが、 $R e$ 数が非常に大きいので入が一定に収束す ると考え、同じ方式で計算することとする。

置き換え型の流れは、完全な分離流である が、管周の摩擦損失は二相がホールドアップ の割合に応じて負担することとなる。また気 相は液相に置き換えられているので、二相の 境界で流速の違いによる摩擦損失は単一流の 乱れのなかでしか考慮されず独自な形では存 在しない前提となる。

\section{b. 2 完全分離モデル ( $S_{2}$ モデル)}

第二に、空気及び水が完全に分離して流れ るのは同じであるが、二相別々に圧力損失計 算を行い、その際、二相の断面形状、潤辺を 考慮するモデルが考えられる。分離流のモデ ルで現実的とされているよらに、空気の潤辺 には水と接している面を含み、水の潤辺は、 水と管の接している部分だけとする。つまり、 水面を壁面と同じように空気にとって抵抗が あるものと考え、空気の閏辺には水と接して いる面も含めるものとする。圧力損失は、 Manning 式を用いる。このほか D-W式を用
い、円形管でない形状を円形管と同じように 考える方法もある。径深は円形管の場合直径 の1/4であることから、径深の 4 倍をD-W式 の直径相当と考光計算するものである。この モデルは、Johannessen[6]によって、層状 流、波状流の圧力損失、ボイド率を予測する モデルとして提案され、データに適合すると されている。

以上二つの分離流モデルを考えたが、実際 では空気流が速いため、二相の乱れを生じる と共に、空気流が水流を加速する。また間欠 流などのように管周の摩擦損失の負担も異な ると考えられる。

\section{2. 3 間欠流の圧力損失推算式（合成 モデル T P)}

実際の間欠流を中心とした二相流は混合モ デルと分離モデルの間にあることが実験デー タにより示されている。また、圧力損失が流 速の 2 乗に比例することから次の式を考えた。

$$
\lambda_{\mathrm{Cr}}=\lambda_{\mathrm{CM}}^{\mathrm{m}} \cdot \lambda_{\mathrm{cs}}{ }^{(1-\mathrm{m})}
$$

ここで、 $\lambda_{\mathrm{CT}}$ : 合成の $\lambda_{\mathrm{C}} 、 \lambda_{\mathrm{CM}}$ : 混合流 のときの $\lambda_{\mathrm{C}} 、 \lambda_{\mathrm{cs}}$ : 分離流のときの $\lambda_{\mathrm{C}} 、 0$ $\leqq \mathrm{m} \leqq 1$ とすると、圧力損失は、次式 (4-11) となる

$$
\begin{aligned}
\mathrm{d} P_{\mathrm{f}} / \mathrm{d} z= & \left(\lambda_{\mathrm{CT}} / 2 D\right) \cdot\left\{\left(J_{\mathrm{A}} \cdot \rho_{\mathrm{A}}+J_{\mathrm{L}} \cdot \rho_{\mathrm{L}}\right) \cdot\right. \\
& \left.\left(J_{\mathrm{A}}+J_{\mathrm{L}}\right)\right\}
\end{aligned}
$$

合成モデルは $J_{\mathrm{A}}$ ないし $J_{\mathrm{L}}$ が 0 に近付くと、 単相流の状態の式となる。重み付け係数 $m$ を

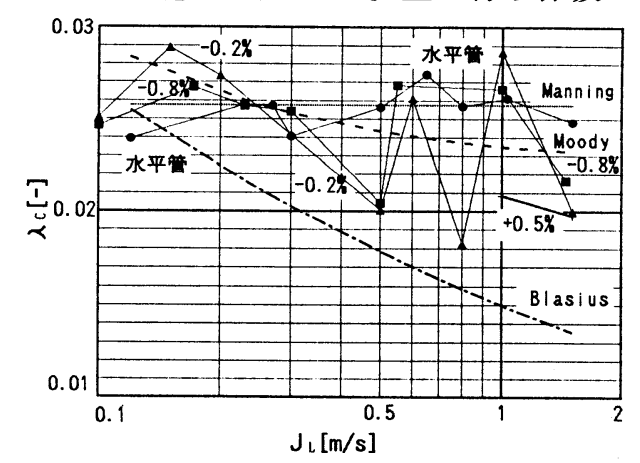

Fig.4.1 $J_{L}-\lambda_{c}$ (converted friction coefficient) in single-phase water flow. 
以下のように考えてみる。管径が数 $\mathrm{mm}$ と小 さい場合、水と空気は交互に流れ、その圧力 損失は、気液が混合して流れるモデル（Mモ デル）と、ほぼ同様の摩擦損失となる。管径 が大きくな間欠流で空気スラグが流れると、 フィルム部分を生じるようになる。フィルム 部分は分離流に近い状態と考えられる。この ことは水の流れが相対的に遅くなっていくこ と、および圧力損失が小さくなることを意味 する。これから、圧力損失に支配的な影響を 持つと考えられる液相の流速は小口径管では 大きく、大口径管では小さくなっていくと考 えられ、重み付け係数 $m$ は小口径管では大き く、口径が大さくなるにつれ小さくなるもの と思われる。 $m$ を実験值から求めた。 Manning 式による T P 1モデルの係数 $\mathrm{m}$ は、分離流を 除いた $200 \mathrm{~mm}$ 管水平管の実験データから 0.62 といら值が得られたので $200 \mathrm{~mm}$ 管のモデル では0.6を用いて比較することとする。

$300 \mathrm{~mm}$ 管の係数 $\mathrm{m}$ は 0.3 内外であった。な お、Moody 式を用いた場合の $200 \mathrm{~mm}$ 管の係 数 $\mathrm{m}$ は 0.81 で、 $300 \mathrm{~mm}$ 管では 0.5 内外であっ た。Fig.4.2に水の容積流束 $J_{\mathrm{L}}$ が $1 \mathrm{~m} / \mathrm{s}$ の場 合の Manning 式の計算式の比較を示す。 $\lambda_{c}$

（D-W式の摩擦係数に換算する）で表して いる。この場合、分離流及び合成モデルは置 換型 $\mathrm{S}_{1}$ と $\mathrm{T} \mathrm{P}{ }_{1}$ 、完全分離型 $\mathrm{S}_{2}$ と $\mathrm{T} \mathrm{P}_{2}$ の二 種を示している。 $J_{\mathrm{A}}$ が小さいとき混合型と 分離型の差は小さく、 $J_{\mathrm{A}}$ の増加と共に差が広 がり、30m/s位で混合型は $\mathrm{S}_{1}$ 型の 7 倍、 $\mathrm{S}_{2}$

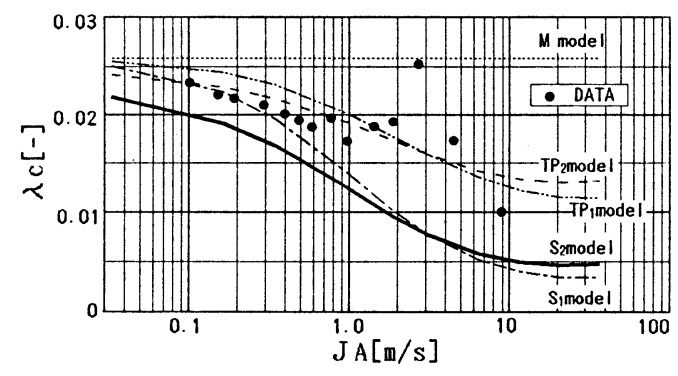

Fig.4.2 $J_{\mathrm{A}}-\lambda_{\mathrm{c}}$ (converted friction coefficient) in $\mathrm{J}_{\mathrm{L}}=1.0 \mathrm{~m} / \mathrm{s}$ ).

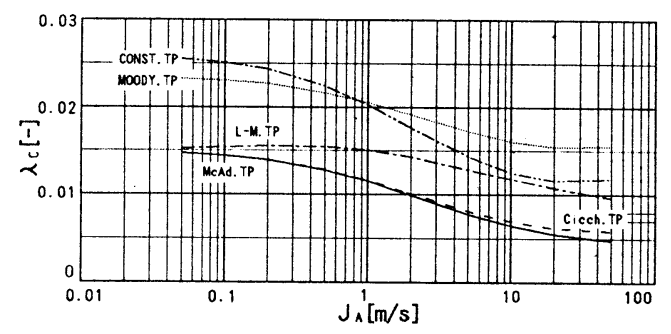

Fig.4.3 $J_{\mathrm{A}}-\lambda_{\mathrm{c}}$ (converted friction coefficeint) in $\mathrm{J}_{\mathrm{L}}=1.0 \mathrm{~m} / \mathrm{s}$.

型の 5 倍程度となる。 $\mathrm{S}_{1}$ 型は $J_{\mathrm{A}}$ が小さいと

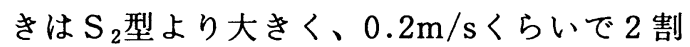
程度の差があるが、 $J_{\mathrm{A}}$ がそれより大きくな ると差が縮まって $4 \mathrm{~m} / \mathrm{s}$ 位で同じ值となり、 以後逆転する。

Moody式の場合、混合モデルMの摩擦係 数は $J_{\mathrm{A}}$ の増加によって多少下がるが Manning 式と同じ様な傾向を示す。

合成モデルは分離流の影響を受ける。Fig. 4.3に同じケースの各種の合成モデル（ $\mathrm{TP}_{1}$ 型）及びL-M相関を示す。 D-W式で粘性係 数の McAdmas、Cicchitti型、Moody型、 L-M 相関、入一定の0.026としたものを示す。 を一定にしたものは Manning とほぼ一致し データを代表するものである。管の粗さによっ て調整できるManning 型及び Moody 型を 除き、他の推算值はデータより低い值となっ ている。ただし、 $J_{\mathrm{A}}$ の増加による換算摩擦

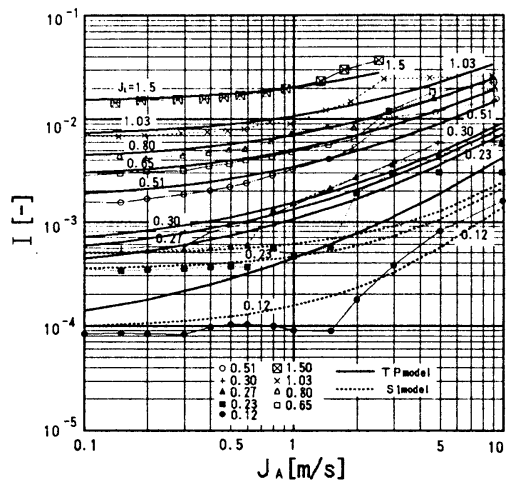

Fig.4.4 $J_{\mathrm{A}}-\mathrm{I}$ (water head loss gradient)in horizontal flow. 


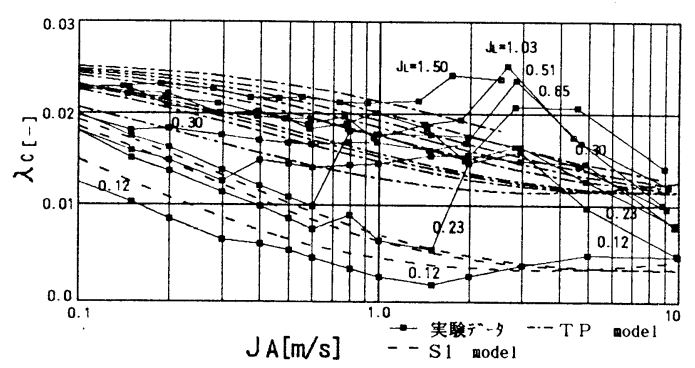

Fig.4.5 $J_{\mathrm{A}}-\lambda_{\mathrm{C}}$ (converted friction coefficient) in horizontal flow.

係数の変化はほぼ同じであり、水単相流の 入 $\mathrm{C}$ が一致していれば、あまり差がないこと がいえる。L-M相関は実験データに比較し て小さめに算定されている。これも基本の摩 擦係数を小さく与えているからであり、基本 の摩擦係数が合ら $300 \mathrm{~mm}$ 管の間欠流では実 験データより大きい值となっている。L-M 相関は基本的に $\mathrm{M}$ モ゙゙ルに近い值を示す。

分離流モデルは、原理的およびデータとの 近似性は $\mathrm{S}_{2}$ の方が良いようであるが、計算 が非常に複雑になることと、あまり差がない ことから実験データとの比較は $\mathrm{S}_{1}$ モデルを 主に用いることとする。

\section{3 実験データとの比較}

Fig. 4.4 亿 $200 \mathrm{~mm}$ 水平管の実験結果と合成 モデルの比較を示す。

合成モデルの流速式は Manning 式を用い ている。ここでは分離流（層状流）状態も含 め $J_{\mathrm{L}}$ の小さい状況のものも示している。ま た合成モデルとあわせ分離流に合ら分離モデ ルも示している。

換算摩擦係数 $\lambda_{\mathrm{C}}$ で表したグラフをFig.4.5 に示す。 $\lambda_{\mathrm{C}}$ のデータは、おおむね右下がり になっているが、データのばらつきのせいか $J_{\mathrm{A}}$ が $3 \mathrm{~m} / \mathrm{s}$ 位の所で高い值を示すものが多い。 また、分離流と層状流の区分が読み取れる。

\section{5. ボイド率}

\section{1 ボイド率の回帰式}

これまでの文献では気相流速 $V_{\mathrm{A}}$ は全容積 流束 $J_{\mathrm{T}}=J_{\mathrm{L}}+J_{\mathrm{A}}$ に比例するものが多く、ボ
イド率はJ $J_{\mathrm{T}} に$ 対して一定の值をもつこととな る。今回の実験データは、 $V_{\mathrm{A}}$ に対して $J_{\mathrm{L}}$ が 数倍の影響要素があることを示しており、別 の回帰式を考えた。

実験結果の分布から、圧力損失と同じよう に間欠流が混合流と分離流の中間に位置する と考えた。

\section{(1)混合流の場合}

ボイド率 $\alpha_{\mathrm{M}}$ は次のように表せる。

$$
\alpha_{\mathrm{M}}=J_{\mathrm{A}} /\left(J_{\mathrm{A}}+J_{\mathrm{L}}\right)
$$

\section{(2)分離流の場合}

\section{a . 置き換え型}

分離流のボイド率 $\alpha_{\mathrm{S}}$ は、二層に分離して 流れることから、便宜的に空気を同じ断面積 で同じ圧力損失で流れる水に置き換えてみる。 ここで摩擦損失は流れる物質の密度に比例す るとした。潤辺などの要素を無視すると、

$$
\rho_{\mathrm{A}} \cdot\left(J_{\mathrm{A}} / \alpha_{\mathrm{S}}\right)^{2}=\rho_{\mathrm{L}} \cdot\left(J_{\mathrm{AL}} / \alpha_{\mathrm{S}}\right)^{2}
$$

ここでJ $J_{\mathrm{AL}}$ は空気流を同じ断面積、かつ同 じ圧力損失で流れる置き換えた水の容積流束 である。式 $(4-12)$ と同様に、 $\alpha_{\mathrm{s}}$ は次式とな る。

$$
\alpha_{\mathrm{S}}=0.0346 \cdot J_{\mathrm{A}} /\left(0.0346 \cdot J_{\mathrm{A}}+J_{\mathrm{L}}\right)
$$

\section{b. 分離型}

上と下に分かれた二相の圧力損失が同じと なるようなボイド率を求める。この場合、二 相の占める断面積に応じて径深を求めて、圧 力損失が等しくなるような両相の流量を計算 していくことになる。

分離型は層状流の状況を表すものであるが、 計算方法が複雑になる。

(3)合成モデル

Fig. 5.2に $J_{\mathrm{L}}$ が0.3 0.8m/s、Fig. 5.3に $J_{\mathrm{L}}$ が0.8〜 $1.5 \mathrm{~m} / \mathrm{s}$ ときの混合流と分離流のボイ ド率を示す。

曲線は混合、分離モデル両方とも同じパター ンのS字状になる。また間欠流のボイド率の 実験データは混合流と分離流の中間に位置し、 そのS字曲線のパターンも似ていることから、 
ボイド率の回帰式として次式を基本に考えた。

$$
\begin{aligned}
& V_{\mathrm{A}}=J_{\mathrm{A}}+J_{\mathrm{L}} \cdot k_{\mathrm{L}}+0.35 \cdot(g \cdot D)^{0.5}(5-3) \\
& k_{\mathrm{L}}: \text { 液相流量換算係数 }
\end{aligned}
$$

気相流速はこれまでの一般式と同様に容積 流束に応じて増加する第一、第二項と、靜水 中気泡の上昇速度の第三項で構成するものと した。これから、次式が考えられる。

$$
\alpha=J_{\mathrm{A}} /\left(J_{\mathrm{A}}+J_{\mathrm{L}} \cdot k_{\mathrm{L}}+0.35 \cdot(g \cdot D)^{0.5}\right)
$$

下り勾配管においても分離流でなく間欠流 になると、下流の方が低い圧力を示すように なり、同じ様に気泡の下流への移動があり上 式が適用されると考えた。式 $(5-3)$ で第三 項の速度は $0.49 \mathrm{~m} / \mathrm{s}$ と実験範囲の $V_{\mathrm{A}}$ と比較 して小さいので、 $J_{\mathrm{L}}$ と $J_{\mathrm{A}}$ の比が一定ならば ボイド率はほぼ同じとなる。

\section{2 データの解析}

\subsection{1 気相流速}

データから $V_{\mathrm{A}}$ の回帰式を求める。この際、 分離流とばらつきの多い、ボイド率 $5 \%$ 末満 のデータをはずした。データは水平管と上り 勾配管 2 種を用いた。

回㷌式は、 $V_{\mathrm{A}}=b_{1} \cdot J_{\mathrm{L}}+b_{2} \cdot J_{\mathrm{A}}+b_{3}$ とし、 係数の值を求めた。Table 1 亿結果を示す。

$$
b_{3} \text { を } 0.35 \cdot(g \cdot D)^{0.5} \text { とすると } 0.49 \mathrm{~m} / \mathrm{s} \text { とな }
$$
る。

$b_{3}$ を回㷌式で求めた場合は $0.34 \sim 0.86 \mathrm{~m} / \mathrm{s}$ となる。これから $k_{\mathrm{L}}$ を 3 としてデータと比 較することとした。 $300 \mathrm{~mm}$ 管の場合 $k_{\mathrm{L}}$ は 4 と推定される。

気相流速はJ $J_{\mathrm{T}}$ の1.2倍といら結果が多い。 これは $20 \mathrm{~mm} \sim 50 \mathrm{~mm}$ 管の実験が、これまで 主であったためと思われる。今回のボイド率 の回帰式は $J_{L}$ を何倍か重み付けする点で、 これまでの結果と異なる。ただし、Thom[7]

Table 1 Coefficients of correlation.

\begin{tabular}{|c|c|c|c|c|}
\hline Coefficient & Horizontal & $0.2 \%$ up & $0.8 \%$ up & Total \\
\hline $\mathrm{b}_{1}$ & 3.53 & 1.84 & 2.98 & 2.71 \\
\hline $\mathrm{b}_{2}$ & 1.03 & 1.09 & 1.01 & 1.05 \\
\hline
\end{tabular}

による蒸気一水系の式は今回の実験に合ら。 管径が違う場合の $V_{\mathrm{A}}$ を考えた場合、直径数 $\mathrm{mm}$ の時は流れをみると気相と液相が交替で 流れ、空気流にフィルムを生じない間欠流が 主で $V_{\mathrm{A}}$ は $J_{\mathrm{T}}$ と同じと考えられ、口径 $20 \sim 50$ $\mathrm{mm}$ の時に $J_{\mathrm{T}}$ の 1.2 倍の滑りがおきること、 また圧力損失の解析より液相の実速度がこれ まで考えられているよりも遅いことを考える と、口径200〜 300 mm管で $J_{\mathrm{L}}$ の 3 倍位の滑り があってもそら無理はないと考えられる。

\section{2.2 水平管および上り管のボイド率 実験結果}

Fig.5.1は $200 \mathrm{~mm}$ の水平、0.2\%上り勾配、 $0.8 \%$ 上り勾配管のボイド率と $J_{\mathrm{A}}$ の関係を示 す。 $J_{\mathrm{L}}$ の範囲はグラフを見やすくするため、 低いエリアである $0.1 \mathrm{~m} / \mathrm{s} \sim 0.27 \mathrm{~m} / \mathrm{s}$ とて いる。

水平管の分離流と見なされる部分を除さ、 一定の傾向を示している。

Fig. 5.1に $200 \mathrm{~mm}$ 管の実験データと回帰モ デルの值を合わせて示す。回帰モデルは、 $J_{\mathrm{L}}$

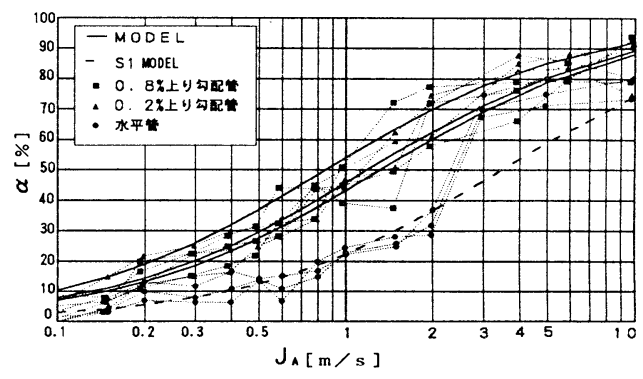

Fig.5.1 $J_{\mathrm{A}}-$ void fraction $\alpha\left(J_{\mathrm{L}}=0.10 \sim 0.27 \mathrm{~m} / \mathrm{s}\right)$.

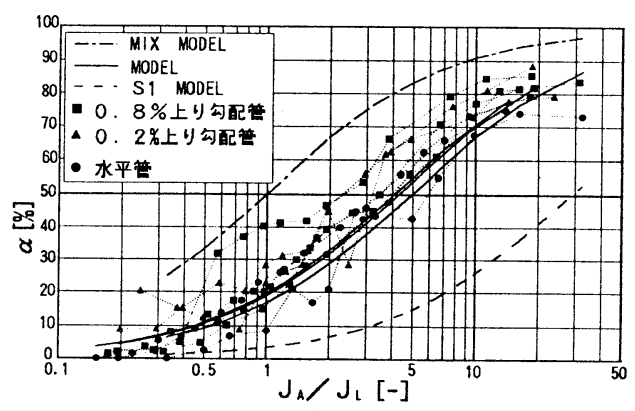

Fig.5.2 $J_{\mathrm{A}}-$ void fraction $\alpha\left(J_{\mathrm{L}}=0.30 \sim 0.80 \mathrm{~m} / \mathrm{s}\right)$. 


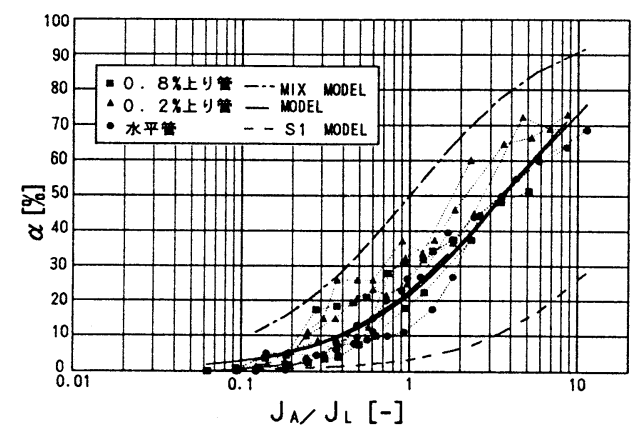

Fig.5.3 $J_{\mathrm{A}}$-void fraction $\alpha\left(J_{\mathrm{L}}=0.80 \sim 1.50 \mathrm{~m} / \mathrm{s}\right)$.

が0.12,0.23,0.27m/sのケースを示す。水平 管では $J_{\mathrm{L}}$ が小さいとき分離流を示す。この ボイド率は分離流のモデルと同じ傾向を示す。

分離流モデルは、 $J_{\mathrm{L}}$ が $0.12 \mathrm{~m} / \mathrm{s}$ のケースを 示す。Fig.5.2、Fgi.5.3に同じとく回帰モデ ルの值を示す。

$300 \mathrm{~mm}$ 管実験結果 $[1]$ では上り勾配がある とボイド率が下がる傾向を示したが、200mm 管ではデータの精度は向上したものの勾配に よる差が認められなかった。このため、 $300 \mathrm{~mm}$ 管の実験データをビデオテープでチェッ クしたところ、二相流の流速が増加して間欠 流の度合が進むと、ボイド率が低く示される 傾向があることがわかった。再検討の結果、 $300 \mathrm{~mm}$ 管でも下り勾配では勾配の影響を受 けるが、緩い上り勾配でボイド率が下がるこ とは言えないという結果となった。別途実施 した $300 \mathrm{~mm}$ 管の 45 度上り勾配実験では、流 速が上昇し、ボイド率が20\%ほど低下するこ とが実験結果のエアリフト解析から推定され る。

\subsection{3 下り勾配のボイド率}

Fig. 5.4に0.5\%下り勾配の実験データと式 を示す。下り勾配管では $J_{L}$ が小さいときは いわゆる自然流下の状況になる。勾配に見合っ た流速になるよう水位が決まる。回帰式では 開水路の Manning 式による断面式からボイ ド率を計算している。

空気流量が増えてきて、分離流のバランス が乱れると摩擦損失が増加する。この部分は 間欠流に移行する領域のようである。この境

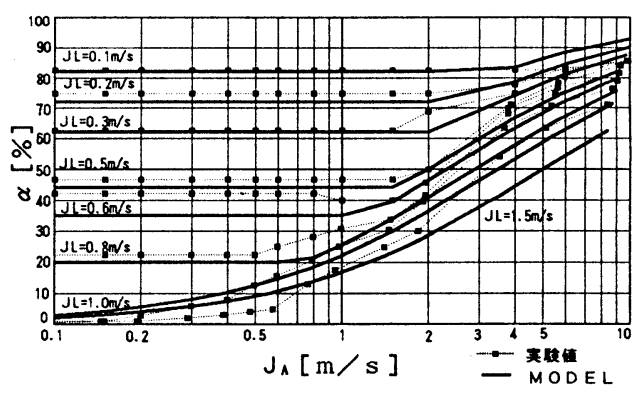

Fig. 5.4 $J_{\mathrm{A}}$-void fraction $\alpha$ in pipe gradient $0.5 \%$ down flow.

界は間欠流のボイド率回㷌式線である。この 境界に達すると一定であったボイド率が急に 変化するようになるが、圧力損失の方も、そ れまで下り勾配の損失に一致して一定であっ たものが、上昇を示すようになる。別の表現 をすると、下り勾配のボイド率は自然流下と 間欠流のボイド率の高い方を示し、一致する ところが分離流と間欠流の境界線と考えるこ とができる。流動様式（Fig.3.3）に、流動 様式から判定した分離流と間欠流の境界線 (FLOW PAT.)、ボイド率から算定した境 界線 (VOID.)、摩擦損失から算定した境界 線(FR.LOSS)、摩擦損失にエアリフト効果 （この場合マイナスになる）を加えた損失か ら算定した境界線(FR.LOSS + AF. EFF)、 を示す。

ボイド率から算定した境界線は、J $J_{\mathrm{L}}$ が小 さいとき、境界線(FR.LOSS+AF.EFF) と 同じ線上にあり、少し分離流の方に入り込ん でいる。各境界線は傾向は似ているが一致し たり離れたりしている。この範囲が遷移領域 であるためと想定される。

$300 \mathrm{~mm}$ 管の $0.5 \%$ 下り勾配実験結果も 200 $\mathrm{mm}$ 管と、ほぼ同じような結果を示した。

\section{6. 勾配のある管の圧力損失}

\section{1 上り勾配管の王力損失とエアリフト ポンプの理論}

上り勾配管の中では、空気の流れが水の落 下を食い止める働きを示す。これは、エアリ フトポンプの概念であり、この面からの解析 
を行った。エアリフトの中の流れは、その構 造から垂直の二相流となる。Reinemann 他 [8]によれば、管内の摩擦損失を無視して、 管内流の平均密度をもとにエアリフトポンプ の圧力バランスを考えると、

$$
\rho \cdot g \cdot Z_{\mathrm{s}}=\rho \cdot g \cdot(1-\alpha) \cdot\left(Z_{\mathrm{s}}+Z_{1}\right)
$$

ただし、 $Z_{1}=$ リフト高(ポンプの揚程)、 $Z_{\mathrm{s}}=$ 浸水高(水中部分の長さ)である。

管内の圧力損失を無視すると、エアリフト 効果率はボイド率と同じ值となる。

実際には圧力バランスの上で、管内に取り 込まれる水の加速のため、および管内の摩擦 損失のための圧力降下を考えなくてはいけな い。ただし、延長の長い直管では、管内に入っ てくる水の加速のための圧力降下は少ない

以上は垂直管のェアリフト効果についての 考えであるが、管が傾斜した状態を考えてみ る。この場合圧力のバランスは、傾斜管の垂 直成分についてみると垂直管とおなじように 考えられる。Stanislav 他[10]は、間欠流の 圧力損失の計算の際、傾斜による圧力勾配変 化の式として $\rho_{\mathrm{TP}} \cdot \sin \theta$ を与えており、この 值はボイド率によるエアリフト効果と同じで ある。Kokal 他 $[9]$ は $25.8 \mathrm{~mm} 、 51.2 \mathrm{~mm}$ 、 $76.3 \mathrm{~mm}$ の3種類の口径の管を用いて、水平、 \pm 1 度、 5 度、9 度の勾配の実験を行い、圧 力損失とボイド率を測定しているが、上り勾 配のケースで、 $J_{\mathrm{L}}$ が小さい場合に、 $J_{\mathrm{A}}$ が大 きくなるにつれて圧力損失が本来大きくなる ところなのに、逆に小さくなっていきエアリ フト効果を示している。

\section{2 エアリフト効果算出式}

傾斜管の場合、その高さ変化のため流れの 位置エネルギーも圧力測定の要素となってく る。満管流のとき、上り管では下流が上流と の水位差分だけ圧力が高くなる。

このため圧力変化は、水位差分を換算して 計算する。二相流の場合は、混合液の比重が 変わるため水位差より、ボイド率の分だけ実 際の高さによる圧力差は小さくなる。これを
エアリフト効果と呼ぶことにする。摩擦損失 を無視した場合は、エアリフト入口の圧力と 位置エネルギーの合計よりエアリフト出口の 圧力と位置エネルギーの合計の方が大きくなっ ており、圧力損失で考えるとエアリフト効果 はマイナスの值となる。エアリフト効果は上 り勾配で働く。下り勾配では複雑な表れ方を し、層状流の状態では表れず、間欠流に移行 すると逆に、圧力損失が大きくなる方に㗢く と考えられる。エアリフト効果を算定する上 でボイド率は重要な役割を示す。ボイド率は、 実験結果から求められた回帰式(5-4)を用い、 実験結果と比較することにする。

\section{3 傾斜管のデータとの比較}

二層スラグ流のボイド率の式が与えられ、 またボイド率からエアリフト効果が大まかに 求められることから、これまで関連付けがな いまま、独立して扱っていた、ボイド率と圧 力変化のエアリフト効果を連動して考えるこ とができる。各ケースのエアリフト効果につ いて実測值と比較することにする。

\section{3．1 上り勾配管 $(0.8 \% 、 0.2 \%)$}

$0.8 \%$ 上り勾配管の圧力損失勾配をFig. 6.1 に示す。なお、図中の数值は、 $J_{L}$ の值であ る。データとモデル式の傾向は、お拈むね合っ ている。また、エアリフト効果をFig.6.2 示す。 $0.2 \%$ 上り勾配管の圧力損失勾配は、 式とデータが合っていない。測定精度のため と考えられる。 $300 \mathrm{~mm}$ 管では最大 $3 \%$ まで の実験を行っているが、勾配が大きいほど圧 力損失データから計算したエアリフト効果と モデル式と合っている結果を示した。

\subsection{2 下り勾配管 $(0.5 \%)$}

Fig.6.3に圧力損失水頭を示した。データ の圧力損失は、 $5 \times 10^{-3}$ より小さいものはな い。

水平流であれば間欠流であっても、 $5 \times$ $10^{-3}$ より小さい摩擦損失で流れる場合もある が、下り勾配管では、水が勾配による位置工 ネルギーを全て消費し、結果的に大きな圧力 水頭損失を示す。ただし、この圧力損失は水 についてであって、空気の摩擦損失はこれに 


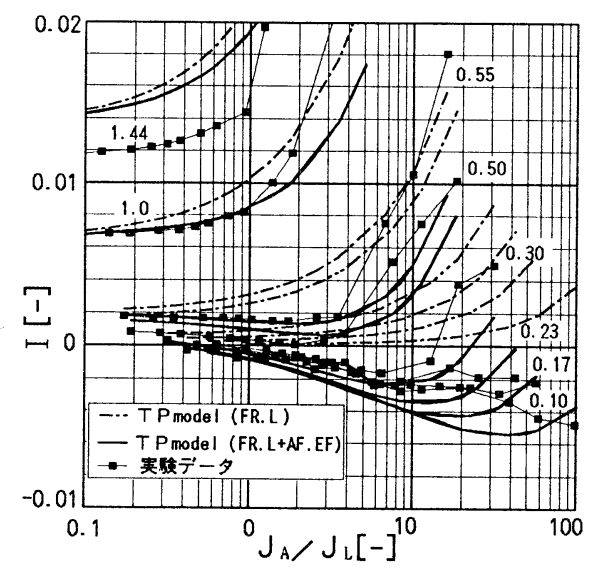

Fig.6.1 $J_{\mathrm{A}} / J_{\mathrm{L}}-\mathrm{I}$ (Water head loss gradient). in pipe gradient $0.8 \%$ up flow.

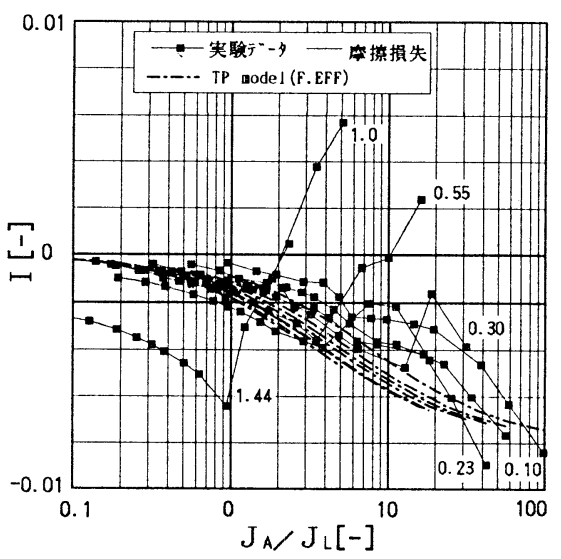

Fig.6.2 $J_{\mathrm{A}} / J_{\mathrm{L}}$-effect of airlift in pipe gradient $0.8 \%$ up flow.

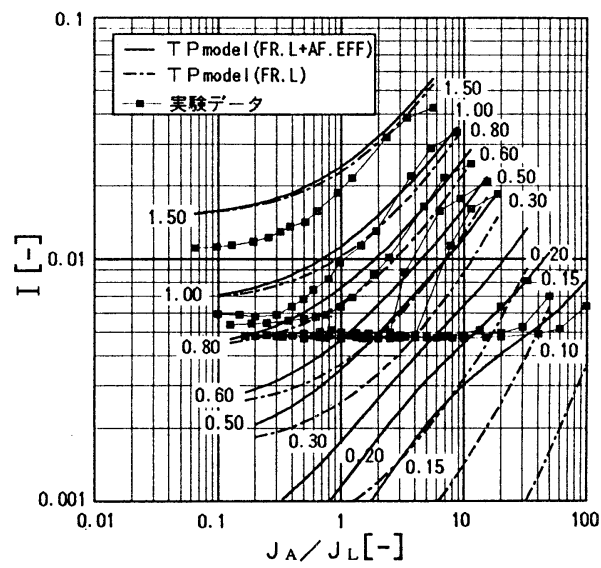

Fig.6.3 $J_{\mathrm{A}} / J_{\mathrm{L}}$-effect of airlift in pipe gradient $0.5 \%$ down flow.
較べて少ないと推定される。同じJ $J_{\mathrm{L}}$ のもと でJ $J_{\mathrm{A}}$ が増加し分離流の流れが保持できなく なった状態で間欠流に移行するとともに圧力 損失勾配も $5 \times 10^{-3}$ を超える。データ、算定 式とも、間欠流になった後の $J_{\mathrm{A}}$ の增加に対 する圧力水頭損失の増大の傾きは大きい。デー タの圧力損失から水平管圧力算定值を引いた 値と、エアリフト効果算定值との比較をして みると、データのばらつきは大きいが、プラ ス（エアリフト効果としてはマイナス）の性 格を示している。この傾向は、 $300 \mathrm{~mm}$ 管に おいても示されている。

\section{7. 結 論}

前回の $300 \mathrm{~mm}$ 管に続いてロ径 $200 \mathrm{~mm}$ 管の 水・空気二相流の実験を行い、以下の結論を 得た。

\section{1 摩擦による圧力損失}

本実験データと文献值を比較すると、

(1) 分離流の圧力損失は同じ傾向を示す。

(2) 間欠流と、水単相流との圧力損失の比 は本実験データの方が低い傾向を示す。

間欠流において圧力損失は、次のモデルの 間に位置するものとして回帰モデルを検討し た。

\section{(1)混合流モデル（2)分離流モデル}

二相流の摩擦損失は、密度が大きく、摩摖 損失が高くなる液相の流速に主として支配さ れるものと大まかに考えられる。大口径の二 相流では、ボイド率の実験結果が、これまで 言われているものよりも小さいことから、夜 相の平均流速が低くなり摩擦損失が小さくな るものと推定される。これから、間欠流の摩 擦損失は、管径が小さい場合、混合流に近つ き、管径が大きくなっていくと分離流に近つ くと考えられる。200mm管および $300 \mathrm{~mm}$ 管 の間欠流は、混合流モデルと分離流のモデル の合成モデルにより圧力損失データを回㷌す ることができた。分離流の摩擦損失データは、 分離流モデルによる計算式で回帰することが 出来た。 


\section{2 ボイド率}

間欠流のボイド率は、圧力損失同様に、文 献值より低めの傾向を示した。空気平均流速 は水容積流束の $3 \sim 4$ 倍、空気容積流束の 1 倍の影響を受け、これよりボイド率の回帰式 が得られた。分離流のボイド率データは、分 離流モデルによる計算值と合う結果を示した。 間欠流のボイド率も管径の影響を受け、小ロ 径管では混合流に近く、管径が大きくなるに つれ分離流に近づくと考えられる。

\section{3 勾配による影響}

上り勾配では、ボイド率から計算した平均 密度を持つ流体と位置エネルギー関係が同じ 状態となる。摩摖による圧力損失にこれを加 えて勾配管の圧力が表される。

下り勾配管では、一定の気相流速までは自 然流下、間欠流としての摩擦損失勾配計算值 が、下り勾配を超えると間欠流の状況になり、 摩擦損失勾配は上り勾配管と同じょうに計算 でさる。

自然流下の状態のボイド率は、開水路の断 面計算で概ね表すことが出来る。

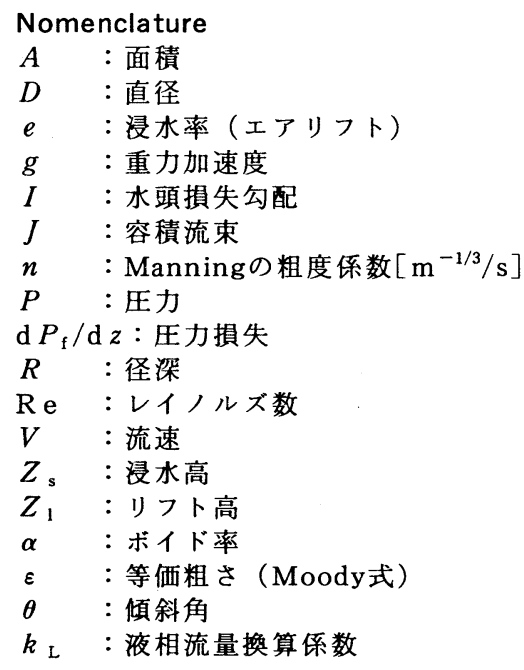

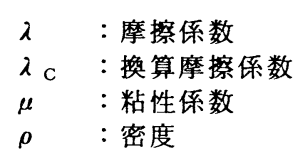
$[-]$
$[-]$
$[\mathrm{p} \mathrm{a} \cdot \mathrm{s}]$
$\left[\mathrm{kg} / \mathrm{m}^{3}\right]$

添字

A : 気相

C : 換算

L : 液相

L0 : 水単相流

$\mathrm{M}$ : 混合流モデル

$S, S_{1}, S_{2}$ : 分離流モデル

$\mathrm{T}, \mathrm{TP}:$ 二相

参考文献

[1] 亀田泰武、森田泰治郎、混相流、4巻、3号, 219-249(1990).

[2] Weisman J., Flow Pattern Identification in Co-Current Vapor-Liquid Flow, Proc. Japan-Us Seminer on Two-Phase Flow Dynamics, Kobe (1979).

[ 3 ] 井上宇市,空気調和ハンドブック、丸善、1982.

[4] R.W.Lockhart and R.C.Martinelli,Chemical Engineering Progress, Vol.45, No.1,Jan., 39-48(1949).

[ 5 ] 日本機械学会、気液二相流技術ハンドブック、 コロナ社、1989.

[6] Thorbjorn Johannessen, A Theoretical Solution of the Lockhart Martinelli Model for Calculating Two-Phase Flow Pressure Drop and Hold up, Int. J. Heat Mass Transfer, vol.15,pp.1443-1449, Pergamon Press (1972).

[7] Thom,J.R.S, Prediction of Pressure Drop during Forced Circulation Boiling Water, Int.J.Heat Transfer, 10, p1767-1778(1967).

[8] D.J.Reinemann et., Theory of Small-Diameter Airlift Pumps, Int. Journal, Multiphase Flow, Vol.16, No.1 pp.113-122(1990).

[9] J.F.Stanislav, S.Kokal and M.K. Nichols en, Gas Liquid Flow in Downward and Upward Inclined Pipes, The Canadian Journal of Chemical Engineering, Vol.64, p881-890 (1986).

[10] S.L.Kokal and J.F. Stanislav, An Experimental Study of Two-Phase Flow in Slightly Inclined Pipes-2.Liquid Holdup and Pressure Drop, Chemical Engineering Science, Vol.44, No.3,pp681-693(1989).

[11] 秋田県（財団法人建設技術研究所受託）、秋 田湾・雄物川流域下水道压送管実験委託（勾 配管・水平管) 報告書 $(1992-3)$. 